\title{
Primary State Formation Processes on Bronze Age Crete: A Social Approach to Change in Early Complex Societies
}

\author{
Borja Legarra Herrero
}

\begin{abstract}
The formation of a state on Crete at the beginning of the second millennium BC has usually been considered under the secondary state paradigm. Most explanations rely on the role of conspicuous consumption and emulation mechanisms at a time when Cretan elites were exposed to the developed stratified systems of the east Mediterranean. A careful review of the data, especially those derived from funerary contexts, struggles to identify such dynamics but reveals a varied range of identities being negotiated and redefined simultaneously at the local and regional level. Informed by ethnographic parallels, an alternative model for Crete is proposed in which change is understood as a social phenomenon that involved a wide proportion of the population and brought broad benefits that sustained the adoption and development of the transformed systems. Crete is presented as a rich archaeological example that may also help in rethinking similar processes in other parts of the Mediterranean and further afield.
\end{abstract}

\section{Introduction: the Cretan challenges}

Major changes occurred on the island of Crete at the beginning of the second millennium $\mathrm{BC}$, to the extent that this has been normally considered a state formation process (Figs. 1 \& 2; Chapman 2008; Schoep 2010). How this came to be is the subject of a long-standing-and still raging - academic debate, fuelled by the rich archaeological evidence from the island (Cherry 1986; Legarra Herrero 2012; 2014a; Manning 1997; Renfrew 1972; Schoep \& Tomkins 2012; Whitelaw 2012).

$<$ Figures 1 \& 2 near here $>$

The current debate on state formation on Crete is structured around the relation of external influences with internal agency (Cherry 2010; Legarra Herrero 2011a; Manning 2008; Parkinson \& Galaty 2007; Schoep \& Knappett 2004; Watrous 2012). Most of these approaches characterise the developments on the island as a top-down transformation in which elites impelled by internal competition and their efforts to emulate their east Mediterranean counterparts led changes that ended in the formation of states on Crete.

Recent work allows us to explore state formation processes on Crete within a more detailed temporal and geographical framework. Diverging local trajectories hint at differing processes of change and shift the focus towards more diverse internal dynamics of change (Legarra Herrero 2014a; Relaki 2004; Whitelaw 2012). At a more theoretical level, many of the traditional referents used in the explanation of change on Crete, such as the role of exotica or the interaction of elites with the rest of the population, have been the subject of recent reassessments (Kienlin 2012; Robb \& Pauketat 2013; Routledge 2014; Stein 1999) that still need to be considered in the archaeological context of the island. There are therefore several reasons to review the mechanisms of change that led to Cretan state formation.

In this changing academic framework, I would argue that it may prove valuable to re-consider the Cretan case as a set of predominantly 'primary state' processes. The 
'primary state' perspective aims to focus the explanatory attention on the resolution of internal processes to the island. 'Secondary state' paradigms (Price 1978) ultimately explain changes in the context of external influences and as a logical reaction of the local culture to these influences. This article reverses the starting point of analysis: the development of state formation on Crete was mainly due to internal decisions and an idiosyncratic cultural configuration that enable innovations to become stable. External influences are considered as one of the many elements that Cretan populations took into account in their processes of transformation, but not necessarily as the decisive ones. The ultimate explanation resides in why Cretans chose to create a state organization and how they managed to solve the internal tensions to find a new cultural balance. The switch in perspective leads to important repercussions in the way we explain change, particularly raising questions about the central role that elites have traditionally been ascribed in state formation explanations, and opens up the debate to include the agency of broader segments of the population.

In this sense, 'primary' should not to be considered as opposed to a 'secondary state', but as a framework to encourage us to think more carefully about the ways the internal reconfiguration of power may have occurred and the roles of the social actors that took part in the processes (Blanton \& Fargher 2008; Carballo et al. 2014; Routledge 2014). While this article will test some of the long-standing views of the role of external links, it is not intended to erase external factors from our explanations, nor to dismiss leaders and elites as unimportant. The main goal is to establish a more detailed discussion about the specifically Cretan mechanisms of change and to emphasize the unique decisions that led to state formation on Crete. It is hoped that this will also establish a better connection between the study of prehistoric Crete and broader discussions on early state formation.

\section{Defining state formation on Crete}

The major weaknesses of the term 'state' have been laid bare in the last couple of decades in Cretan archaeology (Damilati \& Vavouranakis 2011; Hamilakis 2002b; Whitelaw 2004) and elsewhere (Lull \& Micó 2011; Routledge 2014; Yoffee 2005; 2010). Most authors agree that the term too strongly evokes a checklist inspired by Mesopotamian and Egyptian examples that explain little of actual processes; such checklists have tended to focus on material traits that ignore other key elements of state formation processes such as legitimacy and ideology (Peregrine 2012; Smith 2011). In the case of Crete, the term 'state' refers to a package of changes that differ from the classic checklist (Schoep \& Knappett 2004; Whitelaw 2004). The nature of the first palaces is unclear, but it seems that they constituted a kind of building that was qualitatively different to earlier architecture (Vansteenhuyse 2002) and to their east Mediterranean counterparts (Driessen 2002). Their role as a place for social gatherings seems more prominent than their possible use as the residence of an elite (Driessen 2002; Vansteenhuyse 2002). Survey data from several areas of the island point towards a hierarchical settlement configuration, with sites containing palace buildings sitting at the top (Whitelaw 2012). The size of the known palatial settlements became much larger during MM IA (around 40 ha for Knossos and 20 ha for Phaistos) and achieved a scale comparable to other urban centres in the east Mediterranean (Whitelaw 2001; 2012). A large part of the island's population, however, may have been outside the direct economic, social or political control of the larger sites (Haggis 2002). The widespread use of seals and sealings suggests a relatively elaborate administrative 
system (Weingarten 1990), even though it may not have been highly centralized or directly comparable with east Mediterranean administrative practices (Schoep 1999).

This package of changes demonstrates a significant departure from the historical trajectory of Crete before the MM IA period. Third-millennium BC Crete is comparable to regions in the west and central Mediterranean, as hierarchization processes on Crete seem to have been part of short-lived 'boom and bust' processes (Legarra Herrero 2012) that were typical in the Mediterranean during the fourth and third millennia BC (Broodbank 2013). It also sets Crete apart from other neighbouring regions such as Cyprus, mainland Greece and southwest Anatolia that did not undergo such major developments until centuries later (Lewthwaite 1983). In this sense, the use of the term 'state' provides an indication of the scale of the quantum leap that Cretan societies underwent at the end of the third millennium $\mathrm{BC}$, even when the nature of this 'state' may have been unique to Crete.

\section{The secondary state perspective: the 'prestige' model on Crete}

The sudden changes on the island have usually been consideredin relation to the new engagement of island communities with the wider east Mediterranean (e.g. Sherratt 1993; Sherratt \& Sherratt 1991) at the beginning of the Middle Bronze Age. In the archaeological record this is identifiable as a new wave of material and ideological connections that appeared on Crete at the end of the third millennium BC coinciding with the other major changes explained above (Cherry 2010; Wiener 2013a). The way these influences have been linked to the development of states on Crete differs widely. The traditional diffusionist point of view, in which institutions and ideas were transplanted from the Near East and Egypt to the island (e.g. Xanthoudides 1924) and which envisions Crete as a largely passive receiver of social, ideological and political institutions, is still advocated in recent studies (Warren 1995; Watrous 1998; 2012; Weingarten 2005).

A more complex and nuanced view of the interaction between external influences and internal processes is now predominant (Cherry 2010; Manning 2008; Parkinson \& Galaty 2007; Schoep 2006; Schoep \& Knappett 2004). Most of the views are based on the principles presented in Cherry's seminal work on peer-polity interaction on Crete (Cherry 1986). He argued that internal competition between several different polities within the island constituted the main dynamic that led to social and political changes. External behaviours, ideas and material were used by Cretan elites as ideological ordnance in their rivalry, helping to accelerate the changes. Cherry's emphasis on internal dynamics has somehow diluted under other models that include world-system theory (Parkinson \& Galaty 2010; Sherratt 1993; Sherratt \& Sherratt 1991), postcolonial theory (Damilati \& Vavouranakis 2011), as well as ideas about the ideological significance of distance and travel (Broodbank 1993; Schoep 2006), conspicuous consumption (Renfrew 1972) and the value of exotica (Colburn 2008). Current models also borrow heavily from the dual process theory (Blanton et al. 1996; Parkinson \& Galaty 2007; Schoep 2006; Schoep \& Knappett 2004), particularly as it is increasingly clear that state formation on Crete lacks the leadership ideologies of many of the east Mediterranean states. Using the 'corporate' paradigm, it has been suggested that communal ritual, shared group identities and practices better describe the elements of socio-political competition in MM I Crete. Only in later periods would the system have moved towards a more starkly hierarchical society (Parkinson \& Galaty 2007; Schoep \& Knappett 2004). 
Though these models have emphasized the public and communal elements of Cretan state formation, the ultimate reliance on external influences in the explanatory model has eventually handed the actual agency of change to Cretan elites. Elites have been defined as the leaders of larger groups, but these groups have remained largely in the background and elites have become independent social agents. In our efforts to integrate internal and external dynamics, elite groups have been promoted to key figures that channelled the external influences into a new kind of organization on the island. Elites were rapidly able to use off-island connections to augment their own social and political position and to direct changes towards a more differentiated society. Elites would have used new materials arriving from the east Mediterranean to intensify the symbolic aspects of social competition, and in the process, strengthen their own power (Cherry 1986; Driessen 2012; Manning 1994;2008; Parkinson \& Galaty 2010, 41; Schoep 2006; 2012; Wiener 2013a). They would have controlled the arrival of these imports to the island, used exotic material culture and adopted foreign customs to create a distinct identity based on distance and restricted knowledge, and such items would have been used in conspicuous consumption contexts to boost elites' social position. Elites became increasingly preoccupied with gathering resources that helped them to procure such off-island items, accelerating the extent of their political control and economic administration (Sbonias 1999; Schoep 2006; 2010). Following these emulation and conspicuous consumption dynamics, elites also sponsored the introduction of new techniques to the island that helped them to create exclusive crafted items that matched those of their Near Eastern counterparts (Knappett 1999; Wiener 2013a). The transformative value of exotica and the link with powerful east Mediterranean elites are seen as the main strategies employed by local elites to convince Cretan societies of the legitimacy of increasing inequality and the introduction of new political and social institutions (Manning 2008; Parkinson \& Galaty 2007; Schoep 2006).

This set of explanations, which for simplicity will be labelled the 'prestige model', in many ways emphasizes the secondary nature of state formation on Crete. Without the east Mediterranean models and influences, local elites would have never been able to establish such a comprehensive range of changes on the island. The model has normally been claimed to be supported by the better-known funerary data. Prestigious items, particularly those with foreign links, have been seen as high-value items that marked high-status individuals on Crete mainly in the increasingly differentiated elite tombs (Cultraro 2001; Watrous 1998). The appearance of examples of monumentality has been seen as further proof of the rising power of the elites, and large funerary complexes such as Chrysolakos at Malia and Tholos B at Archanes-Phourni (Fig. 3) have been presented as elite burial places. In the particular case of Chrysolakos, it has been suggested that the complex may have imitated the architecture of an Egyptian mastaba, reflecting local elite attempts to emulate Egyptian counterparts (Watrous 1994, 729). Such changes in the funerary record would have been accompanied by a stronger individual ethos (Tsipopoulou 2008) as represented by the introduction of individual types of burials on Crete (Maggidis 1998). The large corporate groups of the Early Bronze Age cemeteries were replaced by smaller tombs and a major emphasis on individual identity, paving the way for stronger inequalities (Manning 2008).

<Figure 3 near here> 
There are good reasons to revise this prestige model. While the general structure of competition between Cretan communities is well supported by the archaeological record, the characterization of this competition and the way it affected the different social components that formed the Cretan populations has been the subject of less scrutiny (Hamilakis 2002a; Schoep \& Knappett 2004). A growing number of archaeological studies are questioning top-down approaches to change and are reconsidering the relative roles of elites and broader social groups in socio-political change (Blanton \& Fargher 2008; Carballo et al. 2014; Kienlin 2012). The idea that a few individuals can manipulate large sections of the population through material and ideological means is increasingly seen as difficult to defend, particularly as the expected powerful elites remain ill defined in the archaeological record (Legarra Herrero in press). A reassessment of the relationship of elites with broader social groups is long overdue, requiring that we recognize that most, if not all, of the different elements of a society can be active agents and part of social negotiations. The inclusion of a broader social spectrum in our models therefore impacts the way we approach change. Connections to the wider world become less significant in the investigation of change, and the study of the renegotiation of the rate and balance of power within Cretan populations becomes particularly relevant.

From the material record point of view, the idea that imported material culture was attached to exclusive use, and that it was imbued with high values related to distance and east Mediterranean elite ideologies, has been questioned recently by several authors (Legarra Herrero 2011b; Stein 1999; Wengrow 2010). Off-island materials may have carried fewer imported meanings than normally assumed and therefore have been more open to manipulation by Cretan populations. External materials could have embodied contingent and variable values depending on who used them and on the specific cultural and social contexts in which they were used. This type of material needs therefore to be interpreted through the detailed evaluation of the contexts in which they were consumed.

It is at this juncture that the Cretan context presents its real strength for the study of early complex societies. Not only does it facilitate a debate on explanations of how change unfolded, but it also allows the foundation of such a discussion on a detailed review of an extensively known archaeological record. The higher-resolution knowledge of the funerary record provided by recent studies (Bevan 2007; Legarra Herrero 2011b; 2014a; Phillips 2008; Vavouranakis 2007; 2014) encourages a bottomup reassessment of the expectations of the 'prestige' model. The focus on funerary data allows for the study of relevant social arenas of change on Crete as highlighted by the heavy investment of effort and resources in the Middle Minoan IA (MM IA; Fig. 2) cemeteries.

\section{Mortuary customs and social differentiation in MM I Crete}

\section{Cemetery structure}

After a period of major investment in the construction and furnishing of tombs during the EM IIA phase, the Cretan mortuary record seems to have gone relatively quiet in EM IIB (Legarra Herrero 2009). Very few cemeteries seem to have been in use at this time, with abandonment identified in well-understood necropoleis such as Archanes-Phourni (Papadatos 2005) and Gournia (Soles 1992). It seems probable that this low point in cemetery use carried into EM III, but new detailed ceramic sequences seem to indicate that, at some point during this short period, interest in the mortuary domain increased 
again (Brogan 2013; Legarra Herrero 2014a). The creation of new cemeteries, new buildings in existing cemeteries, and the deposition of significant amounts of material inside and outside the tombs, document a major phase of investment in the most wellknown cemeteries. During the following MM IA period, the boom in the use of tombs reached its zenith ,only to decrease again in the MM II period (1850-1750 BC), with most cemeteries being abandoned by MM III (1750-1675 BC) (Legarra Herrero 2014a).

This revived activity during the later EM III and MM IA periods retained traditional Cretan mortuary customs such as the exclusive use of communal tombs and traditional funerary architecture like the tholos tombs. The MM I funerary deposits in the tombs were subject to the same type of disturbances found in earlier tombs (Triantaphyllou 2009). The items were not associated with particular interments, and even in the tombs in which clay coffins (larnakes) were used with the interments (Vavouranakis 2014), the human remains and grave goods were still found heavily disturbed and mixed together.

This legacy was, however, combined with a completely new way of using the cemeteries. Architecturally, the cemeteries became much more complex: most cemeteries included more tombs but also saw a proliferation of non-funerary buildings and spaces (Legarra Herrero 2014a). The new tombs not only speak of larger populations, but also of certain group identities becoming more important (probably small kinship units, e.g. nuclear families/households) within the community (here defined as the larger group living in the same village or town that share a common identity). Cemeteries seem to show a new configuration of smaller social groups, as illustrated by the more than a dozen tombs constructed in the MM IA period at Archanes-Phourni (Sakellarakis \& Sapouna-Sakellaraki 1997). The tholos cemeteries in many cases saw the addition of a second and third tomb, e.g. Platanos (Legarra Herrero 2011b).

The appearance of new tombs was complemented with a new interest in constructing other types of buildings in the cemetery and delimiting communal spaces immediately outside the tombs. These new areas changed the focus of the cemeteries from the tomb and the interred individuals to funeral activities outside the tombs and the participants (Legarra Herrero 2014a). They also seem to indicate different scales of practice in the cemetery. The case of Agia Triada (Fig. 4) shows a series of built complexes related to the tholos that, given their differing arrangements and assemblages, seem to have served diverse practices by different types of groups (Cultraro 2004). The open areas associated with such complexes were often paved and in many cases included benches and altars, such as at Petras (Betancourt 2012) and Gournia (Soles 1992), and seem better designed to host larger groups than the buildings. Deposition in the buildings and open areas is relatively similar, and it is normally constituted by large quantities of ceramic cups and jugs indicative of drinking and/or libation activities (Legarra Herrero 2014a). There is relatively little evidence for food processing and consumption in this specific period; the best-known evidence for food consumption in cemeteries comes from the EM II period (Branigan 2008). In general, the architectural changes created a diverse range of areas in the cemeteries that may indicate more elaborated sets of rites with different types of groups involved in each stage. Funerals comprising several ceremonies would have congregated people regularly in the necropoleis. Later stages of the funeral sequences could have been attended by people from a broader geographical area, as there would have been time for the news to travel and attendance to be organized. More elaborate and regular 
mortuary-related activities would have helped to convert the cemeteries into regional meeting points.

$<$ Figure 4 near here $>$

The material assemblages inside the tombs also experienced major changes. Tomb deposits are dominated by ceramic jugs and cupes, paralleling the ceramic deposits found outside tombs,. The range of non-ceramic items in the tombs narrowed from earlier periods: copper, silver and gold items and figurines became rarer. Other items seem to have been more popular: there was a major increase in the number of sealstones found in tombs, as well as stone vessels (Fig. 5). Scarabs, imported Near Eastern sealstones and Egyptianizing stone vessels are found in the tombs, but they constituted a very small part of the burial assemblages (Fig. 5; see below). As in earlier periods, the distribution of non-ceramic materials reached most tombs (Ferrence et al. 2012; Legarra Herrero 2014a).

$<$ Figure 5 near here $>$

It is possible to identify a focal point at the centre of many cemeteries, represented by a larger tomb with areas for group gatherings outside the burial chamber and what may seem a slightly richer material assemblage. Such a feature is found in all comprehensively known cemeteries for the period, from relatively small ones such as Mochlos (Tombs IV/V/VI; Soles 1988) to larger ones such as Petras (Tomb 2; Tsipopoulou 2012). In all cases, this complex includes a larger-than-average communal tomb at a central location in the cemetery surrounded by an abnormal number of architectural features such as buildings and/or paved open areas. In several cases these associated spaces contained large concentrations of ceramic cups and jugs (Legarra Herrero 2014a). Apart from these common features, the central complex appears more differentiated at larger cemeteries than at smaller ones. Tholos B at Archanes-Phourni (Sakellarakis \& Sapouna-Sakellaraki 1997) and the earliest building at Chrysolakos at Malia (Demargne 1945) had an elaboration of surrounding open spaces and buildings that is not matched elsewhere (Fig. 3). The evidence from the best-dated cases, such as Tholos A at Platanos (Xanthoudides 1924) and Tomb 2 at Petras (Tsipopoulou 2012) indicate that the central tombs contained a richer material assemblage than the rest of the cemetery. As with the architecture, the differentiation of the central complexes was probably starker in certain cemeteries. Agia Triada Tholos A and Platanos Tholos A produced a larger amount of gold items than other well-preserved tombs (Legarra Herrero 2014a). This tends to be accompanied by unusual concentrations of items outside the tombs; in the case of Platanos, the annexe to Tholos A contained not only a large ceramic deposit but also hundreds of stone vessels (Fig. 6; Xanthoudides 1924).

\section{The role offoreign materials}

Major significance has been bestowed upon objects with foreign links in the MM IA period in the prestige model. It was at the very end of the third millennium $\mathrm{BC}$ when a significant number of east Mediterranean items and influences could be identified in the mortuary record of Crete for the first time (Cherry 2010; Phillips 2008). These took the form of actual imports, imitations of foreign items, local items with iconographic resemblances to other cultures and materials locally made but using imported technologies (Warren 1995; Weingarten 2005; Wiener 2013a). It has been suggested 
that new iconographic elements in Minoan seals at this time, such as lions and monkeys, reflected Egyptian and Near Eastern influences (Warren 2005). More secure evidence of contact comes from the deposition of cylinder seals, scarabs and stone vessels imitating Egyptian shapes in the MM IA cemeteries. The presence of such items in tombs has normally been assumed to represent goods deposited with the high-prestige interments of an emerging elite (Colburn 2008; Manning 2008), overlooking some of the contextual information available. A detailed examination of the deposition patterns and contextual evidence of items with off-island links indicates a more nuanced and multilayered social use of these items than is normally recognized (Legarra Herrero 2011a; Phillips 2008; Wengrow 2010).

Imitations of Egyptian stone vessels are found in those contexts where significant numbers of local stone vessels are found, and as far as the limited evidence allows, it is possible to propose that their deposition did not follow a different logic to that of the local vessels in the tombs (Legarra Herrero 2011a). It has been suggested that it is this concentration of stone vessels in specific tombs, rather than that of Egyptian imitations, that needs explanation (Legarra Herrero 2014a). In the case of Platanos, the huge deposition of stone vases outside the tombs suggests a very particular group dynamic in this cemetery, in which a rich tomb was matched by a lavish group ritual large-scale consumption of high-labour goods. The presence of imitations of Egyptian vessels mixed in this assemblage seems to have been a less significant feature.

Scarabs and scaraboid seals are widely distributed in the funerary record (Phillips 2008). There is no discernible pattern in the deposition of scarabs in terms of larger versus smaller cemeteries, apart from the general fact that, as in the case of stone vessels, the deposition of scarabs parallels concentrations of sealstones (Legarra Herrero 2011a). There is a concentration of scarabs in quite unremarkable tombs along the south central coast (Pini 2000), and it is possible that they were used mainly to mark the distinct identity of the communities in the region. As seals started to be used in a regional competition dynamic (Sbonias 1999), scarabs may have been chosen by certain communities to communicate their identity. The fact that several imported scarabs were inscribed with Cretan motifs reinforces the idea that the main role of scarabs was to convey local identities, along with other possible ideas of prestige.

The narrow focus of study on these imported materials, overlooking their associations, has hindered the recognition of broader patterns in the deposition of material assemblages in the tombs, namely a major increase in sealstones and stone vessels in tombs, as well as the use of such items in communal activities outside the tomb chambers. The off-island connections of certain sealstones and stone vessels may express nuances within this pattern, but these finer points remain difficult to define (Wengrow 2010). It seems clear that this material was not mainly related to elite identities as is sometimes assumed, but was a component in the complex set of multilevel relationships that were enacted and materialized at the cemeteries.

\section{Communal and individual identities in Prepalatial Crete}

The funerary record of MM I Crete confirms the long acknowledged fact that there was a distinct lack of clear representations of individual leadership in the Minoan record (Dabney 1995). The royal tomb at Isopata at Knossos in the LM II period (c. $1450 \mathrm{BC}$ ) is the earliest secure example (pending the forthcoming publication of the Temple Tomb) of a monumental tomb probably intended for the use of one or a small number of individuals (Preston 2007). Novelties in the MM IA mortuary record stressed different types of communality, from the commingled remains in each tomb to the large 
commensality rituals at the cemeteries. The introduction of burial containers in the MM I funerary record seems to have formed part of the implementation of new concepts of communality in Cretan tombs (Hamilakis 2014; Legarra Herrero 2014a; Vavouranakis 2014), rather than a sign of a growing individual ethos (Manning 2008; Tsipopoulou 2008). By the MM IA period this use of communal burials had dominated the mortuary behaviour of the island almost exclusively for approximately a millennium (Fig. 1). New MM I cemeteries, such as Apesokari A (Flouda 2013), were based on the construction of a tholos tomb, a form of architecture kept virtually unchanged for 1000 years. This is a rare case in Mediterranean prehistory; there are extremely few examples in the Mediterranean in which individual internments did not form a significant part of the funerary customs at some point in the fourth and third millennia BC. Despite Crete's outward-looking history, individual burial customs from other parts of the Aegean were included only peripherally in the island's mortuary repertoire during the EM I period (Betancourt 2008; Galanaki 2006). Changes in the MM I period introduced important innovations in the way in which death was approached and the persistent maintenance of communal burial by Cretan societies can only be seen as a conscious choice that represents a fundamental element of the way they understood social interaction and organization.

\section{The dialectic nature of the Cretan mortuary record}

This review of the data cannot identify a single instance where the 'prestige' model's expectations of high-value materials in wealthy exclusive burials can be clearly identified in the archaeological record. This is not to say that there were no dynamics of competition and differentiation; however, the depositional practices related to the collective nature of the tombs demonstrate the importance of group identities in the tombs and suggest that the cemeteries present a fluid consideration of different concepts of communal and individual identities at interlocking levels. Social differentiation at the local and regional levels occurred at the same time that community-wide identities were strengthened. The role of materially elusive leading figures cannot be ignored, but these individuals are difficult to recognize in the tombs, let alone to characterise.

The sudden innovations in cemeteries in MM IA may be interpreted as a period of rapid innovation and negotiation within each community, with diverse groups competing through the building of the tombs, funerary practices and associated performances. Within this broad dynamic of local re-configurations of power, larger cemeteries display intra-community differentiation by scaling up common patterns in the construction of tombs and the deposition of materials: i.e. large cemeteries had more monumental central tombs that contained larger numbers of certain materials. The larger tombs do not present a break from the mortuary practices and behaviours typical from most Cretan cemeteries, just a modification in scale. But the larger cemeteries should not be seen solely as a product of more differentiated communities. The communal character of the tombs was maintained, probably indicating that there were still strong dynamics of integration working at the community level. Central tombs at Archanes-Phourni or Malia were not unique only because of their assemblages, but also because they attracted more elaborate furnishing of communal spaces around them. The significance of the central complex seems therefore also to have been associated with the whole community. The more pronounced central complexes identified in the record were the ones that also contained the more distinctive displays 
of community-wide activities. This presents an interesting dialectic in terms of the relationship between differentiation within smaller kinship groups in the cemetery and integrative dynamics at community, and potentially inter-community, level. It implies that there was a rebalance between different types of affiliations and identities, particularly between those related to the household and close kinship links and those concerning the community and its place in a particular geographical locale. The negotiation of these different types of identities would have affected fundamental aspects of the organization of the group, such as political representation, land ownerships and rights of exploitation. It also indicates differences in the way communities approached changes, with certain communities such as Malia and Archanes probably leading the experimentation due to the pressures of their larger population.

To understand how Minoan societies managed to resolve these contradictions successfully and integrate them into a working system, both dynamics need to be understood in a positive feedback relationship. Several authors have recognized that, in the MM I period community, identities seem to have emphasized their position in the landscape, as regional competition appears more marked in the archaeological record (Haggis 1999; Sbonias 1999). The large number of seals found in the tombs in this period can be organized regionally by types and motifs and shows a new interest in projecting community identities in what appear to be expanding exchange systems across large parts of the island (Sbonias 1999). Monumental architecture and lavish funerals could have been means to communicate the strength of a community to their neighbours, particularly as long-winded funerals may have attracted individuals from outside the settlement. New communal sanctuaries at the peaks of some mountains became popular during the MM I period (Nowicki 1994) and they indicate a clear interest in marking the presence of a community in the geo-social landscape of a region. Also during the EM III/MM I periods, the early palaces appear to have been used to host significant gatherings (Driessen 2002; Vansteenhuyse 2002). Together with the new use of cemeteries, there was a whole range of social arenas that were created to be used to negotiate the intricate combination of differentiation and integration dynamics at various political and spatial scales. New practices would have allowed for other types of negotiation to take place that the tradition-laden cemeteries struggled to cover. The other side of the coin for this new era of competition was the more marked defensive character of the settlements in the period (Wiener 2013b), indicating possible violent clashes between communities.

There is also a tension between the common nature of the changes occurring in most cemeteries and individual trajectories for each community. As has been demonstrated in settlement analysis, some particularly large communities, such as Knossos and Malia, were probably developing more rapidly, producing new forms of political, social and economic organization (Whitelaw 2004, 2012). The cases of Platanos,??and?? Archanes-Phourni may have constituted similar communities pioneering complex socio-political organization. Some of these innovating dynamic communities, such as Archanes or Agia Triada, could have seen their efforts truncated early. Variability in the burial record suggests contingent histories of change for each community and complex spatial and temporal patterns that are difficult to trace archaeologically. One should be careful not to mistake the archaeological limitations in chronological resolution with a homogeneous process of change across the island. The location of the larger cemeteries in central Crete also indicates that changes may have occurred first in this part of the island, a large, agriculturally rich and well inter- 
connected region that may have fomented competition. This raises interesting questions about the shared burial features across the island's cemeteries: which elements of the shared behaviour were the result of smaller communities trying to catch up with what was happening in the larger sites and which elements indicate a prior common sociocultural foundation that helped less dynamic communities to adopt the changes rapidly?

\section{Searching for new theoretical frameworks: a social approach to state formation}

Without denying external influences, the Cretan funerary record mainly reflects concerns about the development and negotiation of new relationships within the community and between communities. As they can be traced through the mortuary record, the transformative dynamics were characterized by the balancing of strong ideas of community and collectivity with internal competition and hierarchization in what it seem strong local and regional competitive environments (cf. Hamilakis 2002a; Parkinson \& Galaty 2007; Schoep \& Knappett 2004). What the data summary does not provide is evidence that fits the explanation of change embodied in the 'prestige' model; instead of one-way, top-down processes, it identifies a conjunction of various power relationships working simultaneously. Mechanisms of internal change, such as individualized conspicuous consumption and the symbolic role of exotica in creating differentiation, cannot be easily recognized in the evidence presented. This raises the question of how communal practice and competition interacted with processes of internal differentiation, and how to explain it by taking into consideration the agency of a wider range of sectors in society. It also stresses the presence of strong integrative ties that counterbalanced the identified processes of social competition. How were these contradictions resolved? How did different groups that competed for power within a settlement, at the same time cooperate to strengthen community identities at regional competitive scales? How did monumental cemeteries, shared practices and the materialization of collective identities through valuable material and consumption practices resolve these paradoxes to make change viable in the medium term on Crete as opposed to other regions of the Aegean?

It is not difficult to find theoretical referents that echo the Cretan evidence. Ethnographers such as P. Roscoe and P. Wiessner in New Guinea (Roscoe 2000a,b; 2012; Wiessner 2002; 2009) have reassessed the way power is negotiated in societies with incipient hierarchization. These studies provide a basis to reinterpret the idea of early complexity in archaeology by recognizing the agency of a broader social spectrum and by placing a much stronger focus on negotiation (Carballo et al. 2014; Crumley 1995; Kienlin 2012). In many ways, they provide a valuable update of the ethnographic basis on which many of the ideas of early state formation in the Aegean rely (see also Wolpert 2004; Wright 2004).

Roscoe and Wiessner have stressed that the New Guinea ethnographic data provide a much more fluid picture of mid-range social organization than traditionally understood in the Aegean, characterized by ever-present negotiation between powerful individuals and the social groups they represent. Big-men and/or chiefs (and the line between them is considered as increasingly blurred; Roscoe 2000a) are the heads of particular groups and there is a constant tension between the wants and needs of these individuals and the judgement on their decisions by the group they represent (Roscoe 2000b; Wiessner 2002; see also Hayden \& Villeneuve 2010). The importance of egoist behaviour and personal benefits as factors in leaders' decisions cannot be overlooked (Hayden \& Villeneuve 2010), but there is a growing understanding of early complexity 
as a multi-layered negotiation of vertical and horizontal dynamics between a variety of social actors (Blanton \& Fargher 2008; Carballo et al. 2014; Crumley 1995; Robb \& Pauketat 2013; Schortman 2014). This picture is consistent with the dynamic sociopolitical history of EBA Crete (Legarra Herrero 2012; Whitelaw 2012). The site-specific boom-and-bust trajectories that shaped the archaeological record of Early Bronze Age Crete may reflect a contingent patchwork of dynamic social re-configurations that never had the potential to develop into a stable system. This stresses further the dramatically different nature of the changes in the MM IA period. This was a moment in which novel power relationships managed for the first time to gain traction in a few sites, forming the foundations for further developments in the following periods (Schoep 2010; Whitelaw 2012). Why now and not before?

Ethnographic work can also be used to shed light on the successful aspects of the MM IA changes. Collectives and groups are being increasingly recognized as active and powerful actors that keep leaders under continuous assessment (Roscoe 2000a,b) and can also promote change (Carballo 2012; Saitta 2007). Leaders' acquired or inherited status does not guarantee automatic support and they are required constantly to reinforce the social and economic basis on which their power is built (Roscoe 2000b). Within the range of disparate reasons on which decisions are made, the provision of benefits to the group(s) to which the leader belongs appears as a particularly important motivation (Roscoe 2000b). The nature of the benefits may refer to ideological or material benefits (or both), such as feasts that at the same time bring both types of benefits to the group (Hayden 2001). As we have seen, various new MM IA social arenas on Crete may have provided locales for such activities (MacDonald \& Knappett 2007).

Another main benefit that groups seek and leaders must successfully provide is security, which includes the waging of war. The fact that funerary customs in MM IA seem to be more homogeneous around the island than ever before indicates that communities were more engaged in larger networks of interaction and competition that could also have increased the use of violence as a valid way to deal with some of the challenges of the new interconnectivity. This may have become more acute as some communities became stronger and more dominant than others, leaving smaller communities more vulnerable. The small MM IA settlements of Chamaizi (Lenuzza 2011) and Trypiti (Vasilakis 2010) were located in defensive positions and suggest that violence was a concern for some communities (Wiener 2013b). The guarantee of security relies heavily on numbers: the larger the group, the better its chances to prevail in a conflict. The effort devoted to constructing community identities and potentially wider alliances in the cemeteries may be seen also as a response to the increased threat of violence, and one of the aims of the new practices around the tombs was to increase the group's strength. The integrative dynamics would be particularly important and challenging in larger communities; the significant number of new tombs in the larger cemeteries represents an increase in distinct burial groups that would have put more pressure on the efforts of holding the community together. These larger communities were the ones that would have had to find innovative ways to bind together the larger and more diverse population, ending in solutions that are typical from state organiszation (e.g. administrative practices). The mere construction of larger cemeteries could have been a meaningful act that aimed to organize a work-force for a shared goal; this would have encouraged new links within the community and it could explain why most cemeteries in the MM IA period seemed to undergo constant modifications. The cult activities surrounding the multi-stage funerals would also have built and reinforced social relationships, probably of a different nature than those 
activated during the construction of the individual tombs. These recurrent events would have helped to convert communities of practice into meaningful identities. The benefits of such communal efforts would have been immediately understandable for the people involved. At a basic level, a large and powerful community could have used violence to their advantage, or at least the threat of it could have helped its members to engage advantageously in inter-community social, economic and political relationships. The monumental architecture and the impressive funerary rites would have been an effective means to send messages about the powerful nature of a community to a broader regional audience (Bird \& Smith 2005; Roscoe 2000a).

The Cretan Prepalatial cemetery was an arena in which power negotiations at different but linked scales could be enacted simultaneously. The necropolis became a multifaceted space that allowed the same individuals to achieve a range of social, economic and ideological goals (reproduction, subsistence, security) through constructing and renewing different affiliations (Roscoe 2000b), and to resolve conflicts between these. Given the strong traditional position of cemeteries in Cretan societies, the necropolis may have been well suited to negotiate the different concerns (social status, economic sustainability, security ...) of the diverse interested parties (leaders, nuclear families, larger kinship groups, communities ...). The cemetery interlinked the different scale dynamics in a uniquely powerful context by embedding these practices within a strong ideological and emotional setting: a leader's prestige linked to the strong display in a funeral of the group he represented; a larger tomb indicated the power of a particular group within a community, but it also elevated the prestige of the community that hosted that group. Palaces and peak sanctuaries may soon have followed as additional arenas; given their novel character, these were more suitable for new types of interactions and messages connected at larger spatial and social scales (Wiessner 2002).

This last point brings us back to the about primary and secondary state formation. As top-down processes have been demonstrated to be not the only dynamic taking place, the role of external influences has been difficult to identify as decisive in sociopolitical negotiations. Instead, the record shows specifically Cretan practices of material consumption and social behaviour that lead to questions about the internal negotiations that take place at local and regional scales: Why did changes in some areas of the island achieve a socially critical mass of support? Why was change seen as beneficial by a wide enough group of individuals to secure its long-term adoption? What kind of negotiations took place? How was that change enacted in a manner that was viable in the medium term? Why were some Cretan communities compelled to change?

For this last question, there are no easy answers; there are always reasons for situations to change, and human culture is never in a state of stasis: a time of bonanza may have brought new demographic pressure on the island after the possible 2200 BC climatic event (Brogan 2013; Wiener 2013b); a more internally and externally connected island with the introduction of the donkey and better sailing techniques (Brodie 2008; Whitelaw et al. 1997) may have created a far more regionally interconnected economy and put extra pressure on resources; it is very possible that the situation of the island in a new world of exchange with the east Mediterranean brought new interests and benefits that could be exploited (Legarra Herrero 2011a; 2014b). The focus on internal processes of change does not exclude external factors having a role in the transformations, but rebalances the investigation by focusing on the nature of the contexts in which external influences appeared. 


\section{Conclusions: how we explain change and why Crete matters}

The transformation of Crete into a state society may be mainly understood through mechanisms that integrate social groups through communal practices and a strong collective ethos. This integration seems to have been constructed mainly at the community level, with other strategies pulling in different directions at the same time and at other scales. By MM IA, there was a clearer sense that Crete had become a more connected island, with dynamics working at regional levels now becoming more central to larger social and spatial groups. The benefits of building stronger communities and supporting leading figures may have become more relevant to a wider sector of the Cretan social spectrum. Certain sites may have developed rapidly to become regionally dominant, thereby forcing many other communities to adapt to the new situation. Supporting this process, ideologies may have reinforced the ties that bound the emerging socio-political units against other identities that had a more centrifugal tendency.

Under this general picture, the realities of the process were more complex, chaotic and contingent, and therefore difficult to pinpoint. There would have been winners and losers; some communities would have changed rapidly, while others would have stalled or collapsed, and marginal areas on Crete would never really have engaged in such general trends. There would also have been differences in the timing, with some sites such as Knossos and Malia probably being at the forefront of change, working under slightly different dynamics from the smaller communities deciding whether to follow or reject their example. There are also problems with the definition of the social practices that drove change. Commensality and feasting are widely recognized in the archaeological record (Day \& Wilson 2004; Hamilakis 1998) but their characterization in the specific MM I period is poor (Branigan 2008; Girella 2007). How many people were involved? How often (MacDonald \& Knappett 2007)? Was negotiation mainly enacted by men? Heads of families? A wider group of adults? What was the role of women? Do the later peak sanctuaries and palaces indicate a broader social participation? These are questions that need to be investigated to gain a better understanding of how change might have unfolded in detail.

Crete matters because it is complicated. Crete is a rare archaeological example with a rich corpus of data that allows us to build larger patterns, but also recognize variability through detailed case-studies at the better-documented sites. A careful look at the evidence reveals a situation that is not easy to characterize, and that ill fits traditional expectations typically assumed in secondary state paradigms of external influences helping elites to mark their exclusive status and manipulate power to their benefit. What Crete exemplifies well is the complex set of questions that may help us to identify the convergence of both conflicting and reinforcing dynamics that created the archaeological record. From this set of questions, two emerge as particularly important. First, early complexity is a process involving many contradictory aims and goals; for tentative changes to congeal into a stable system they needed a wide social support. Once processes of elite-led change have been recognized as only a component of the process, a much more intriguing picture emerges, with many more agents taking part. Second, the discovery of a much more varied cast of actors moves the focus of the explanation of change to a consideration of the internal social dynamics. Change is generated through local decisions that were not the exclusive privilege of the individuals at the top of society but also the result of open social negotiations that affected every member of a community. Change was the broadly accepted resolution of 
social negotiation. If it were not broadly or at least strategically supported, it would not have occurred or lasted long. Since changes affected different social actors in different ways, the whole range of social identities must have been negotiated in a variety of social arenas that particularly engaged different social sectors and catered to different social needs. If the onus of understanding change is placed on how entire populations cope and adapt to new conditions, the explanation of early complexity becomes intrinsically endogenous, in which external influences are just elements among the factors that led to local decisions. Crete then leaves us with the question: Could it be more appropriate to consider every instance of socio-political change mainly as a primary process?

\section{Acknowledgements}

This work was inspired by discussion in a workshop in the University of Groningen to which I was kindly invited by Corien Wiersma and Sofia Voutsaki. I am particularly grateful to Todd Whitelaw and Anna Stellatou for sharing with me their thoughts and comments and the reviewers of earlier drafts of this paper for helping me to make my argument stronger and clearer. Mistakes and omissions remain my own.

Borja Legarra Herrero UCL Institute of Archaeology

31-34 Gordon Square

London WC1H OPY

$U K$

Email: b.legarra@ucl.ac.uk

\section{References}

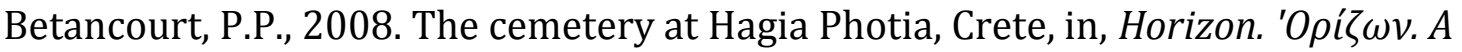
colloquium on the prehistory of the Cyclades, eds. N. Brodie, J. Doole, G. Gavalas \& C. Renfrew. Cambridge: McDonald Institute for Archaeological Research, 237-40.

Betancourt, P.P., 2012. The architecture of the house tombs at Petras, in Petras, Siteia 25 years of excavations and studies. Acts of a two-day conference held at the Danish Institute at Athens, 9-10 October 2010, ed. M. Tsipopoulou. Athens: Danish Institute at Athens, 107-17.

Bevan, A., 2007. Stone Vessels and Values in the Bronze Age Eastern Mediterranean. Cambridge: Cambridge University Press.

Bird, R.B. \& E.A. Smith, 2005. Signaling theory, strategic interaction, and symbolic capital. Current Anthropology 46, 221-48.

Blanton, R.E. \& L.F. Fargher, 2008. Collective Action in the Formation of Pre-Modern States. New York (NY): Springer.

Blanton, R.E., G.M. Feinman, S.A. Kowalewski \& P.N. Peregrine, 1996. A dual-processual theory for the evolution of Mesoamerican civilization. Current Anthropology 37(1), 1-14.

Branigan, K., 1970. The Tombs of Mesara. A study of funerary architecture and ritual in southern Crete, 2800-1700 B.C. London: Duckworth. 
Branigan, K., 2008. Communal ceremonies in an Early Minoan tholos cemetery, in Dioskouri. Studies presented to W.G. Cavanagh and C.B. Mee on the anniversary of their 30-year joint contribution to Aegean Archaeology, eds. C. Gallou, M. Georgiadis \& G. Muskett. (BAR International series S1889.) Oxford: British Archaeological Reports, 15-22.

Brodie, N., 2008. The donkey: an appropriate technology for Early Bronze Age land transport and traction, in Horizon. 'O $\rho$ i $\omega v$. A colloquium on the prehistory of the Cyclades, eds N. Brodie, J. Doole, G. Gavalas \& C. Renfrew. Cambridge: McDonald Institute for Archaeological Research, 299-304.

Brogan, T.M., 2013. 'Minding the gap': reexamining the Early Cycladic III 'gap' from the perspective of Crete. A regional approach to relative chronology, networks, and complexity in the Late Prepalatial period. American Journal of Archaeology 117(4), 555-67.

Broodbank, C., 1993. Ulysses without sails: trade, distance, knowledge and power in the early Cyclades, World Archaeology 24(3), 315-31.

Broodbank, C., 2013. The Making of the Middle Sea. A history of the Mediterranean from the beginning to the emergence of the Classical world. London: Thames \& Hudson.

Carballo, D., 2012. Cooperation and Collective Action: Archaeological perspective. Boulder (CO): University Press of Colorado.

Carballo, D., P. Roscoe, \& G.M. Feinman, 2014. Cooperation and collective action in the cultural evolution of complex societies. Journal of Archaeological Method and Theory 21(1), 98-133.

Chapman, R., 2008. Alternative states, in Evaluating Multiple Narratives. Beyond nationalist, colonialist, ilmperialist archaeologies, eds. J. Habu, C. Fawcett \& J. M. Matsunaga. New York (NY): Springer, 144-65.

Cherry, J. F., 1986. Polities and palaces: some problems in Minoan state formation, in Peer Polity Interaction and Socio-political Change, eds. J.F. Cherry \& C. Renfrew. Cambridge: Cambridge University Press, 19-45.

Cherry, J. F., 2010. Sorting out Crete's Prepalatial off-island interactions, in Archaic State Interaction. The Eastern Mediterranean in the Bronze Age, eds. W.A. Parkinson \& M.L. Galaty. Santa Fe (NM): School for Advanced Research Press, 107-40.

Colburn, C.S., 2008. Exotica and the early Minoan elite: eastern imports in Prepalatial Crete. American Journal of Archaeology 112, 225-46.

Crumley, C. L., 1995. Heterarchy and the analysis of complex societies, in Heterarchy and the Analysis of Complex Societies, eds. R.M. Ehrenreich, C.L. Crumley \& J.E. Levy. Arlington (VA): American Anthropological Association, 1-6.

Cultraro, M., 2001. L'Anello di Minosse. Archeologia Della Regalità Nell'Egeo Minoico. Milan: Longanesi.

Cultraro, M., 2004. La grande tholos di Haghia Triada: nuovi dati per un vecchio complesso. Creta Antica 4, 301-28.

Dabney, M.K., 1995. The later stages of state formation in Palatial Crete, in Politeia, Society and State in the Aegean Bronze Age: Proceedings of the 5th international Aegean Conference, University of Heidelberg, Archäologisches Institut, 10-13 April 1994, eds. R. Laffineur \& W.D. Niemeier. (Aegeum 12.) Liège: Université de Liège, 43-7. 
Damilati, K., \& G. Vavouranakis, 2011. 'Society against the state?' Contextualizing inequality and power in Bronze Age Crete, in State Formation in Italy and Greece. Questioning the neoevolutionist paradigm, eds. N. Terrenato \& D.C. Haggis. Oxford: Oxbow Books, 32-60.

Day, P.M. \& D.E. Wilson, 2002. Landscapes of memory, craft and power in Prepalatial and Protopalatial Knossos, in Labyrinth Revisited. Rethinking 'Minoan' archaeology, ed. Y. Hamilakis. London: Oxbow books, 143-66.

Day, P.M. \& D.E. Wilson, 2004. Ceramic change and the practice of eating and drinking in Early Bronze Age Crete, in Food, Cuisine and Society in Prehistoric Greece, eds. P. Halstead \& J.C. Barrett. Oxford: Oxbow, 45-62.

Demargne, P., 1945. Fouilles Exécutées a Mallia. Exploration Des Necrópoles (1921-1933) I. (Études Crétoises VII.) Paris: Librairie Orientaliste Paul Geuthner.

Driessen, J., 2002. 'The king must die.' Some observations on the use of Minoan court compounds, in Monuments of Minos. Rethinking the Minoan palaces. Proceedings of the international workshop 'Crete of the Hundred Palaces?' held at the Université Catholique de Louvain, Louvain-la-Neuve, 14-15 December 2001, eds. J. Driessen, I. Schoep \& R. Laffineur. (Aegeum 23.) Liège: Université de Liège, 1-14.

Driessen, J., 2012. A matrilocal house society in Pre- and Protopalatial Crete?, in Back to the Beginning: Reassessing social and political complexity on Crete during the Early and Middle Bronze Age, eds. I. Schoep, P. Tomkins \& J. Driessen. Oxford: Oxbow Books, 358-83.

Ferrence, S.C., J.D. Muhly \& P.P. Betancourt, 2012. Affluence in eastern Crete: metal objects from the cemetery of Petras, in Petras, Siteia - 25 Years of Excavations and Studies. Acts of a two-day conference held at the Danish Institute at Athens, 910 October 2010, ed. M. Tsipopoulou. Athens: Danish Institute at Athens, 133-43.

Flouda, G., 2013. Reassessing the Apesokari Tholos A funerary record: preliminary thoughts. Rivista di Archeologia 35, 111-21.

Galanaki, K.E., 2006. Early Minoan burials in the former American Base in Gournes, Pediada, in Proceedings of the $8^{\text {th }}$ International Cretological Congress. Elounda, 1-6 October 2001. Volume A2, Prehistoric Periods, Architecture. Herakleion:

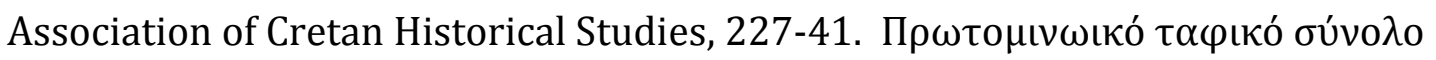

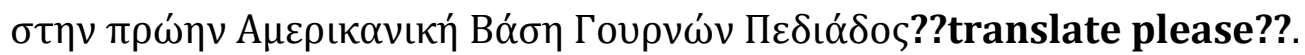

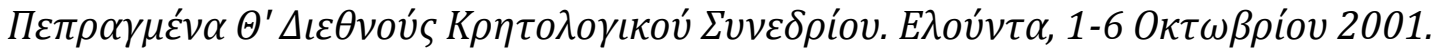

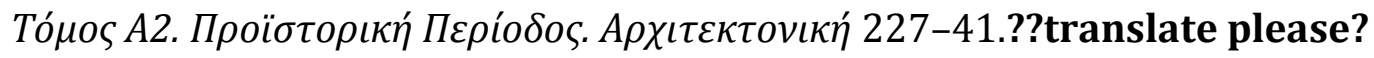

\section{Authors? Place? Publisher??}

Girella, L., 2007. Forms of commensal politics in Neopalatial Crete. Creta Antica 8, 13568.

Haggis, D.C., 1999. Staple finance, peak sanctuaries, and economic complexity in late Prepalatial Crete, in From Minoan Farmers to Roman Traders. Sidelights on the economy of ancient Crete, ed. A. Chaniotis. Stuttgart: Franz Steiner Verlag, 53-85.

Haggis, D.C., 2002. Integration and complexity in the Late Pre-Palatial Period. A view from the countryside in eastern Crete, in Labyrinth Revisited. Rethinking 'Minoan' archaeology, ed. Y. Hamilakis. London: Oxbow Books, 120-42.

Hamilakis, Y., 1998. Eating the dead: mortuary feasting and the politics of memory in the Aegean Bronze Age societies, in Cemetery and Society in the Aegean Bronze Age, ed. K. Branigan. Sheffield: Sheffield Academic Press, 115-32. 
Hamilakis, Y., 2002a. Too many chiefs?: Factional competition in Neopalatial Crete, in Monuments of Minos. Rethinking the Minoan Palaces. Proceedings of the International Workshop 'Crete of the Hundred Palaces?' held at the Université Catholique de Louvain, Louvain-la-Neuve, 14-15 December 2001, eds. J. Driessen, I. Schoep \& R. Laffineur. Liège: Université de Liège, 179-99.??text citation??

Hamilakis, Y., 2002b. What future for the 'Minoan' past? Re-thinking Minoan archaeology, in Labyrinth Revisited. Rethinking 'Minoan' archaeology, ed. Y. Hamilakis. London: Oxbow Books, 2-29.

Hamilakis, Y., 2014. Archaeology and the Senses: Human experience, memory, and affect. Cambridge: Cambridge University Press.

Hayden, B., 2001. Fabulous feasts: a prolegomenon to the importance of feasting, in Feasts. Archaeological and ethnographic perspectives on food, politics, and power, eds. M. Dietler \& B. Hayden. Washington (DC): Smithsonian Institution Press, 2364.

Hayden, B. \& S. Villeneuve, 2010. Who benefits from complexity? A view from Futuna, in Pathways to Power. New perspectives on the emergence of social inequality, eds. T.D. Price \& G.M. Feinman. New York (NY): Springer, 95-146.

Kienlin, T.L., 2012. Beyond elites: an introduction, in Beyond Elites. Alternatives to hierarchical systems in modelling social formations. International conference at the Ruhr-Universität Bochum, Germany, October 22-24, 2009. Teil 1, eds. T. Kienlin \& A. Zimmermann. Bonn: Habelt, 15-32.

Knappett, C., 1999. Tradition and innovation in pottery forming technology: wheel throwing at Middle Minoan Knossos. Annual of the British School at Athens 94, 101-30.

Legarra Herrero, B., 2009. The Minoan fallacy: cultural diversity and mortuary behaviour on Crete at the beginning of the Bronze Age. Oxford Journal of Archaeology 29(1), 29-57.

Legarra Herrero, B., 2011a. New kid on the block: the nature of the first systemic contacts between Crete and the eastern Mediterranean around $2000 \mathrm{BC}$, in Interweaving Worlds: Systemic interactions in Eurasia, 7th to 1st millennia BC. Papers from a conference in memory of Professor Andrew Sherratt. What would a Bronze Age world system look like? World systems approaches to Europe and western Asia 4th to 1st millennia BC, eds. T. Wilkinson, S. Sherratt \& J. Bennet. Oxford: Oxbow books, 266-81.

Legarra Herrero, B., 2011b. The secret lives of the Early and Middle Minoan tholos cemeteries: Koumasa and Platanos, in Prehistoric Crete: Regional and diachronic studies on mortuary systems, ed. J.M.A. Murphy. Philadelphia (PA): INSTAP Academic Press, 49-84.

Legarra Herrero, B., 2012. The construction, deconstruction and non-construction of hierarchies in the funerary record of prepalatial Crete, in Back to the Beginning: Reassessing social and political complexity on Crete during the Early and Middle Bronze Age, eds. I. Schoep, P. Tomkins \& J. Driessen. Oxford: Oxbow Books, 32557.

Legarra Herrero, B., 2014a. Mortuary Behaviour and Social Trajectories in Pre-and Protopalatial Crete. (Prehistory Monograph 44.) Philadelphia (PA): INSTAP Academic Press. 
Legarra Herrero, B., 2014b. The role of gold in South Aegean exchange networks (31001800 BC), in Metalle der Macht - Frühes Gold und Silber/Metals of power - Early gold and silver. 6. Mitteldeutscher Archäologentag: vom 17. Bis 19. Oktober 2013 in Halle (Saale), eds. H. Meller, R. Risch \& E. Pernicka. Halle: Landesamt für Denkmalpflege und Archäologie Sachsen-Anhalt, Landesmuseum für Vorgeschichte Halle (Saale), 467-82.

Legarra Herrero, B., In press. An elite-infested sea: interaction and change in Mediterranean paradigms, in 'Of Odysseys and Oddities': Scales and modes of interaction between prehistoric Aegean societies and their neighbours, eds. B. Molloy \& R. Doonan. London: Oxbow Books.

Lenuzza, V., 2011. 'The whole is a freak': a reassessment of the spatial organization of the Oval House in Chamaizi, Siteia, in $\Sigma \tau \varepsilon \gamma \alpha$ : the archaeology of houses and households in Ancient Crete, eds. K.T. Glowacki \& N. Vogeikoff-Brogan. Princeton (N)): American School of Classical Studies at Athens, 59-70.

Lewthwaite, J., 1983. Why did civilization not emerge more often? A comparative approach to the development of Minoan Crete, in Minoan Society. Proceedings of the Cambridge Colloquium 1981, eds. O. Krzyszkowska \& L. Nixon. Bristol: Bristol Classical Press, 171-83.??text citation??

Lull, V. \& R. Micó, 2011. Archaeology of the Origin of the State: The theories. Oxford: Oxford University Press.

MacDonald, C.F. \& C. Knappett, 2007. Knossos. Protopalatial deposits in early Magazine A and the south-west houses. (BSA supplementary volume 41.) London: British School at Athens.

Maggidis, C., 1998. From polis to necropolis: social ranking from architectural and mortuary evidence in the Minoan cemetery at Phourni, in Cemetery and Society in the Aegean Bronze Age, ed. K. Branigan. Sheffield: Sheffield University Press, 87102.

Manning, S., 1994. The emergence of divergence: development and decline on Bronze Age Crete and the Cyclades. In Development and Decline in the Mediterranean Bronze Age, eds. C. Mathers \& S. Stoddart. Sheffield: John Collis, 221-70.

Manning, S., 1997. Cultural change in the Aegean c. 2200 B.C., in Third Millennium B.C. Climate Change and Old World Collapse, eds. H. Nüzhet Dalfes, G. Kukla \& H. Weiss. London: Springer, 149-71.

Manning, S., 2008. Formation of the palaces, in The Cambridge Companion to the Aegean Bronze Age, ed. C.W. Shelmerdine. Cambridge: Cambridge University Press, 10520.

Nowicki, K., 1994. Some remarks on the Pre- and Protopalatial peak sanctuaries in Crete. Aegean Archaeology 1, 31-48.

Papadatos, Y., 2005. Tholos Tomb Gamma: A Prepalatial tholos tomb at Phourni, Archanes. (Prehistory Monograph 17.) Philadelphia (PA): INSTAP Academic Press.

Parkinson, W.A. \& M.L. Galaty, 2007. Secondary states in perspective: an integrated approach to state formation in the prehistoric Aegean. American Anthropologist 109(1), 113-29. 
Parkinson, W.A. \& M. Galaty, 2010. Introduction: Interaction and ancient societies, in Archaic State Interaction. The eastern Mediterranean in the Bronze Age, eds. W. A. Parkinson \& M. Galaty. Santa Fe (NM): School for Advanced Research, 3-28.

Peregrine, P.N., 2012. Power and legitimation: political strategies, typology, and cultural evolution, in The Comparative Archaeology of Complex Societies, ed. M.E. Smith. Cambridge: Cambridge University Press, 165-91.

Phillips, J., 2008. Aegyptiaca on the Island of Crete in Their Chronological Context: A critical review. (Contributions to the Chronology of the Eastern Mediterranean 18.) Vienna: Verlag der Österreichischen Akademie der Wissenschaften.

Pini, I., 2000. Eleven early Cretan scarabs, in Crete-Egypt. Three Thousand Years of Cultural Links. ??text citation??, ed. A. Karetsou. Athens: Kapon, 107-13.

Preston, L., 2007. The Isopata cemetery at Knossos. Annual of the British School at Athens 102, 257-314.

Price, B. J., 1978. Secondary State Formation: An Exploratory Model, in Origins of the State: The Anthropology of Political Evolution, eds. R. Cohen \& E. Service. Philadelphia: Institute fo the Study of Human Issues, 161-86.

Relaki, M., 2004. Constructing a region: the contested landscapes of Prepalatial Mesara, in The Emergence of Civilisation Revisited, eds. J.C. Barrett \& P. Halstead. Oxford: Oxbow Books, 170-88.

Renfrew, C., 1972. The Emergence of Civilisation: The Cyclades and the Aegean in the third millennium BC. London: Methuen.

Robb, J.E. \& T.R. Pauketat, 2013. From moments to millennia. Theorizing scale and change in human history, in Big Histories, Human Lives, eds. J.E. Robb \& T.R. Pauketat. Santa Fe (NM): SAR Press, 3-33.

Roscoe, P., 2000a. Costs, benefits, typologies, and power: the evolution of political hierarchy, in Hierarchies in Action: Cui bono?, ed. M.W. Diehl. (Occasional Paper 27.) Carbondale (IL): Southern Illinois University at Carbondale, Center for Archaeological Investigations, 113-33.

Roscoe, P., 2000b. New Guinea leadership as ethnographic analogy: a critical review. Journal of Archaeological Method and Theory 7(2), 79-126.

Roscoe, P., 2012. Before elites: the political capacities of Big Men, in Beyond Elites. Alternatives to hierarchical systems in modelling social formations. International Conference at the Ruhr-Universität Bochum, Germany, October 22-24, 2009. Teil 1, eds. T. Kienlin \& A. Zimmermann. Bonn: Habelt, 41-54.

Routledge, B., 2014. Archaeology and State Theory: Subjects and objects of power, debates in archaeology. London: Bloomsbury.

Saitta, D.J., 2007. The Archaeology of Collective Action. (American Experience in Archaeological Perspective.) Gainesville (FL): University Press of Florida.

Sakellarakis, J. A., \& E. Sapouna-Sakellaraki, 1997. Archanes. Minoan Crete in a new light. Athens: Ammos Publications/Eleni Nakou Foundation.

Sbonias, K., 1999. Inter-settlement relations and symbolic representations in Prepalatial Crete, in Eliten in der Bronzezeit. Ergebnisse Zweier Kolloquien in Mainz und Athen. Teil I. Mainz: Verlag des Römischen-Germanischen Zentralmuseums, 1-18.

Schoep, I., 1999. The origins of writing and administration on Crete. Oxford Journal of Archaeology 18(3), 265-76. 
Schoep, I., 2006. Looking beyond the first palaces: elites and the agency of power in EM III-MM II Crete. American Journal of Archaeology 110, 37-64.

Schoep, I., 2010. Making elites: political economy and elite culture(s) in Middle Minoan Crete, in Political Economies of the Aegean Bronze Age. Papers from the Langford Conference, Florida State University, Tallahassee, 22-24 February 2007, ed. D. J. Pullen. Oxford: Oxbow Books, 66-85.

Schoep, I., 2012. Bridging the divide between the 'Prepalatial' and the 'Protopalatial' periods?, in Back to the Beginning: Reassessing social and political complexity on Crete during the Early and Middle Bronze Age, eds. I. Schoep, P. Tomkins \& J. Driessen. Oxford: Oxbow Books, 403-28.

Schoep, I., \& C. Knappett, 2004. Dual emergence: evolving heterarchy, exploding hierarchy, in The Emergence of Civilisation Revisited, ed. J.C. Barrett \& P. Halstead. Oxford: Oxbow Books, 21-37.

Schoep, I. \& P. Tomkins, 2012. Back to the beginning for the Early and Middle Bronze Age on Crete, in Back to the Beginning: Reassessing social and political complexity on Crete during the Early and Middle Bronze Age, eds. I. Schoep, P. Tomkins \& J. Driessen. Oxford: Oxbow Books, 1-31.

Schortman, E.M., 2014. Networks of power in archaeology. Annual Review of Anthropology 43(1), 167-82.

Sherratt, A.G., 1993a. What would a Bronze-Age world systen look like? Relations between temperate Europe and the Mediterranean in later Prehistory. Journal of European Archaeology 1(2), 1-58.??text citation??

Sherratt, A.G. \& S. Sherratt, 1991. From luxuries to commodities: the nature of Mediterranean Bronze Age trading systems, in Bronze Age Trade in the Mediterranean, ed. N.H. Gale. Göteborg: Paul Åströms förlag, 351-86.

Smith, A.T., 2011. Archaeologies of sovereignty. Annual Review of Anthropology 40(1), 415-32.

Soles, J.S., 1988. Social ranking in Prepalatial cemeteries, in Problems in Greek Prehistory: Papers presented at the centenary conference of the British School of Archaeology at Athens, Manchester, April 1986, eds. E.B. French \& K.A. Wardle. Bristol: Bristol Classical Press, 49-61.

Soles, J. S., 1992. The Prepalatial Cemeteries at Mochlos and Gournia and the House Tombs of Bronze Age Crete. (Hesperia Supplement 24.) Princeton (NJ): American School of Classical Studies at Athens.

Stein, G. J., 1999. Rethinking world-systems: power, distance, and diasporas in the dynamics of interregional interaction, in World-System Theory in Practice. Leadership, production, and exchange, ed. N.P. Kardoulias. Lanham (MD): Rowman \& Littlefield, 153-78.

Triantaphyllou, S., 2009. EM/MM Human skeletal remains from east Crete: the Kephala Petras rock shelter, Siteia and the Livari tholos tomb, Skiadi. Kentro 12, 19-23.

Tsipopoulou, M., 2008. Community and the individual in death: the Prepalatial and Protopalatial periods, in From the Land of the Labyrinth. Minoan Crete, 30001100 B.C. Essays, eds. M. Andreadaki-Vlasaki, G. Rethemiotakis \& N. DimopoulouRethemiotaki. Athens: Onassis Foundation/Hellenic Ministry of Culture, 128-33.

Tsipopoulou, M., 2012. The Prepalatial-early Protopalatial cemetery at Petras, Siteia: a diachronic symbol of social coherence, in Petras, Siteia - 25 years of Excavations 
and Studies. Acts of a two-day conference held at the Danish Institute at Athens, 910 October 2010, ed. M. Tsipopoulou. Athens: Danish Institute at Athens, 117-31.

Vansteenhuyse, K., 2002. Minoan courts and ritual competition, in Monuments of Minos. Rethinking the Minoan palaces. Proceedings of the international workshop 'Crete of the Hundred Palaces?' held at the Université Catholique de Louvain, Louvain-laNeuve, 14-15 December 2001, eds. J. Driessen, I. Schoep \& R. Laffineur. (Aegeum 23.) Liège: Université de Liège, 235-45.

Vasilakis, A., 2010. Myrtos Fournou Korifi and Trypiti Adami Korfali: similarities and differences in two Prepalatial settlements in southern Crete, in Cretan Offerings. Studies in honour of Peter Warren, ed. O. Krzyszkowska. Athens: British School at Athens, 353-8.

Vavouranakis, G., 2007. Funerary Landscapes East of Lasithi, Crete, in the Bronze Age. (BAR International Series S1606.) Oxford: Archaeopress.

Vavouranakis, G., 2014. Funerary pithoi in Bronze Age Crete: their introduction and significance at the threshold of Minoan palatial society. American Journal of Archaeology 118(2), 197-222.

Warren, P., 1995. Minoan Crete and Pharaonic Egypt, in Egypt, the Aegean and the Levant: Interconnections in the second millennium BC, eds. W.V. Davies \& E. Schofield. London: British Museum Press, 1-18.??text citation??

Warren, P., 2005. A model of iconographical transfer. The case of Crete and Egypt, in

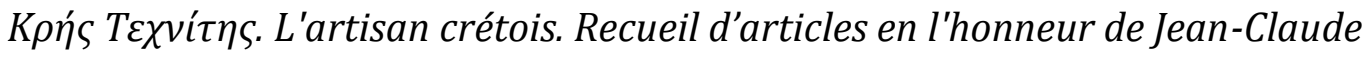
Poursat, publié à l'occasion des 40 ans de la découverte du Quartier Mu, eds. I. Bradfer-Burdet, B. Detournay \& R. Laffineur. (Aegeum 26.) Liège/Austin (TX): Université de Liège/University of Texas Program in Aegean Scripts and Prehistory, 221-7.

Watrous, L.V., 1994. Crete from earliest prehistory through the Protopalatial period. American Journal of Archaeology 98(4), 698-753.

Watrous, L.V., 1998. Egypt and Crete in the Early Middle Bronze Age: a case of trade and cultural diffusion, in The Aegean and the Orient in the Second Millennium: Proceedings of the 50th anniversary symposium, Cincinnati, 18-10 April 1997, eds. E.H. Cline \& D. Harris-Cline. (Aegeum 18.) Liège: Université de Liège, 19-28.

Watrous, L.V., 2012. An overview of secondary state formation on Crete: the Mirabello region during the Bronze Age, in Philistor. Studies in honor of Costis Davaras, eds. E. Matzourani \& P.P. Betancourt. Philadelphia (PA): INSTAP Academic Press, 273-82.

Weingarten, J., 1990. Three upheavals in Minoan sealing administration: evidence for radical change, in Aegean Seals, Sealings and Administration: Proceedings of the NEH-Dickson conference of the program in Aegean scripts and prehistory of the Department of Classics, University of Texas at Austin, January 11-13, 1989, ed. T.G. Palaima. (Aegeum 5.) Liège: Université de Liège, 105-20.

Weingarten, J., 2005. How many seals make a heap: seals and interconnections on Prepalatial Crete, in EMPORIA. Aegeans in the central and eastern Mediterranean. Proceedings of the 10th International Aegean Conference/10e Rencontre égéenne internationale. Athens, Italian School of Archaeology, 14-18 April 2004. Volume II, ed. R. Laffineur \& E. Greco. (Aegeum 25.) Liège/Austin (TX): Université de Liège/University of Texas Program in Aegean Scripts and Prehistory, 759-66. 
Wengrow, D., 2010. The voyages of Europa: ritual and trade in the Eastern Mediterranean, c. 2300-1850 BC, in Archaic State Interaction. The eastern Mediterranean in the Bronze Age, eds. W.A. Parkinson \& M. Galaty. Santa Fe (NM): School for Advanced Research Press, 141-60.

Whitelaw, T.M., 2001. From sites to communities: defining the human dimension of Minoan urbanism, in Urbanism in the Aegean Bronze Age, ed. K. Branigan. Sheffield: Sheffield University Press, 15-37.

Whitelaw, T.M., 2004. Alternative pathways to complexity in the southern Aegean, in The Emergence of Civilisation Revisited, eds. J.C. Barrett \& P. Halstead. Oxford: Oxbow Books, 232-56.

Whitelaw, T.M., 2012. The urbanisation of prehistoric Crete: settlement perspectives on Minoan state formation, in Back to the Beginning: Reassessing social and political complexity on Crete during the Early and Middle Bronze Age, eds. I. Schoep, P. Tomkins \& J. Driessen. Oxford: Oxbow Books, 114-76.

Whitelaw, T.M., P.M. Day, E. Kiriatzi, V. Kilikoglou \& D.E. Wilson, 1997. Ceramic traditions at EM IIB Myrtos, Fournou Korifi, in TEXNH: Craftsmen, Craftswomen and Craftsmanship in the Aegean Bronze Age. Proceedings of the 6th International Aegean Conference /6e Rencontre égéenne internationale, Philadelphia, Temple University, 18-21 April 1996, eds. R. Laffineur \& P.P. Betancourt. (Aegeum 16.) Liège: Université de Liège, 265-74.

Wiener, M.H., 2013a. Contacts: Crete, Egypt, and the Near East circa 2000 B.C., in Cultures in Contact. From Mesopotamia to the Mediterranean in the second millennium B.C., eds. J. Aruz, S.B. Graff \& Y. Rakic. New York (NY): Metropolitcan Museum of Art, 34-45.

Wiener, M.H., 2013b. 'Minding the gap': gaps, destructions, and migrations in the Early Bronze Age Aegean. Causes and consequences. American Journal of Archaeology 117(4), 581-92.

Wiessner, P., 2002. The vines of complexity. Egalitarian structures and the institutionalization of inequality among the Enga. Current Anthropology 43(2), 233-69.

Wiessner, P., 2009. The power of one? Big Men revisited, in The Evolution of Leadership. Transitions in decision making from small-scale to middle-range societies, eds. K.J. Vaughn, J.W. Eerkens \& J. Kantner. Santa Fe (NM): School for Advanced Research Press, 195-222.

Wolpert, A., 2004. Getting past consumption and competition: legitimacy and consensus in the shaft graves, in The Emergence of Civilisation Revisited, eds. J.C. Barrett \& P. Halstead. Oxford: Oxbow Books, 127-44.

Wright, J.C., 2004. The emergence of leadership and the rise of civilization in the Aegean, in The Emergence of Civilisation Revisited, eds. J.C. Barrett \& P. Halstead. Oxford: Oxbow Books, 64-89.

Xanthoudides, S., 1924. The Vaulted Tombs of the Mesara. London: Hodder \& Stoughton.

Yoffee, N., 2005. Myths of the Archaic State. Evolution of the earliest cities, states, and civilizations. Cambridge: Cambridge University Press.

Yoffee, N., 2010. The unbearable lightness of complexity, in Ancient Complexities: New perspectives in Precolumbian North America, ed. S.M. Alt. Salt Lake City (UT): University of Utah Press, 220-25. 


\section{Author biography}

Borja Legarra Herrero is a teaching fellow in Mediterranean archaeology at the UCL Insitute of Archaeology. His main research interests reside in early complex societies in the Bronze Age Mediterranean and in the study of mortuary practices. Other research interests include landscape archaeology and archaeological survey.

$<$ Captions $>$

Figure 1. Sites mentioned in the article.

Figure 2. Chronological framework.

Figure 3. Examples of Large MM I cemeteries: a) Mallia cemetery in MM IA; b) Chrysolakos complex in MM IA; c) Archanes-Phourni cemetery in MM IA; d) Tholos B complex in MM I (with LM modifications).

Figure 4. Agia Triada MM IA cemetery.

Figure 5. Platanos MM IA cemetery. (After Branigan 1970, 12, fig. 2.)

Figure 6. Seals and stone vessel assemblages in MM I tombs: a) seals and stone vessels in Cretan tombs; b) stone vessels and Egyptian imitations in MM I tombs; c) seals and scarabs in MM I tombs. 


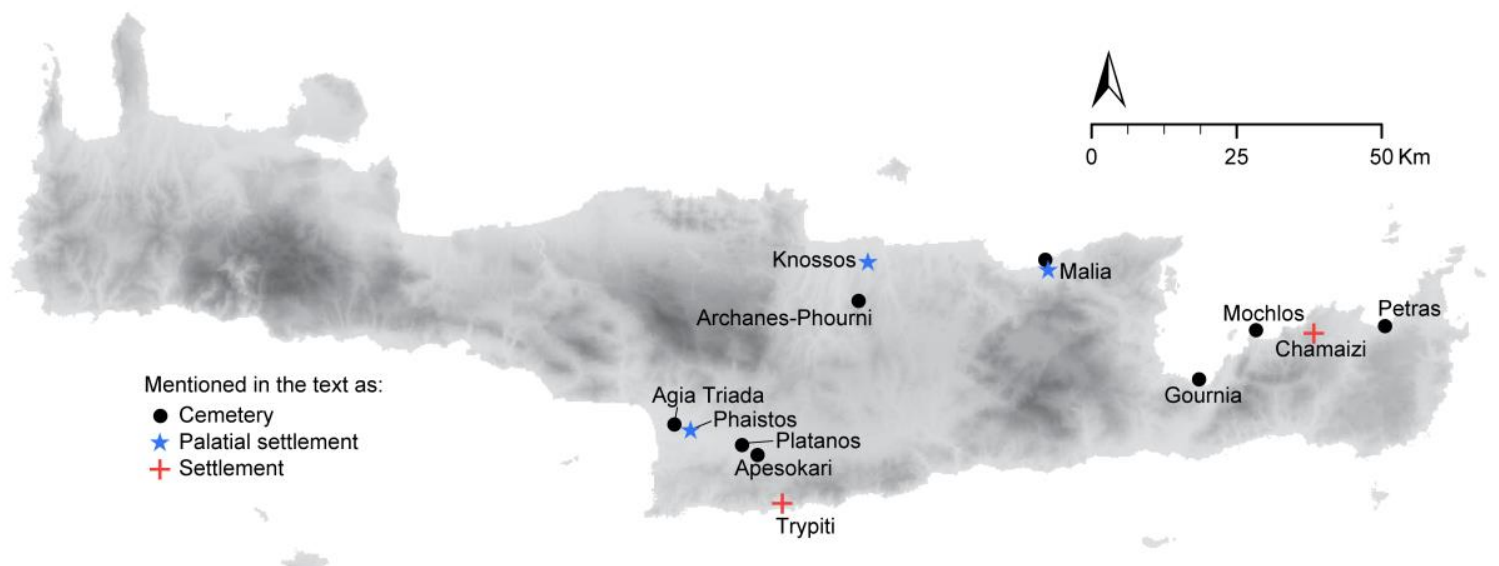




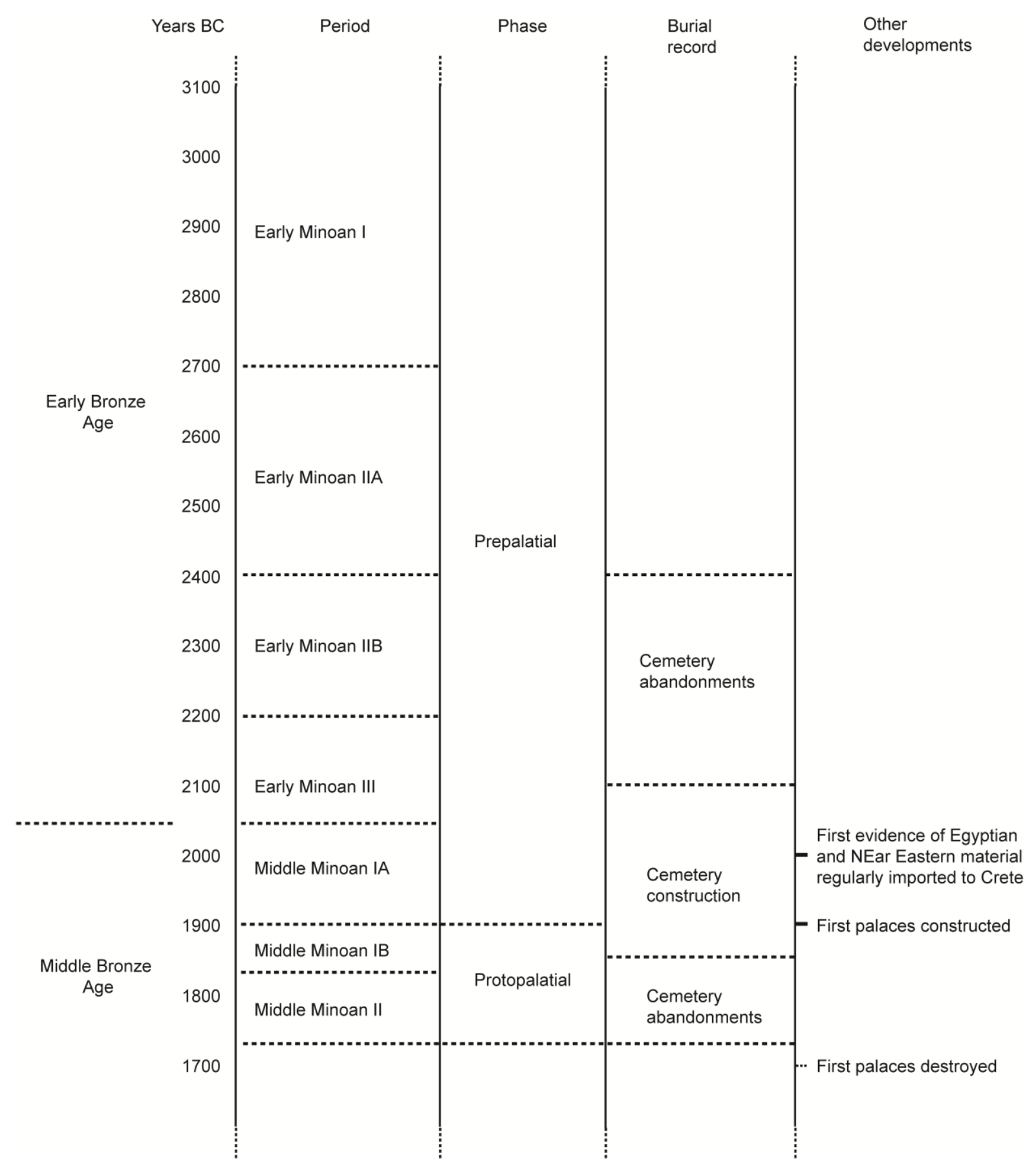



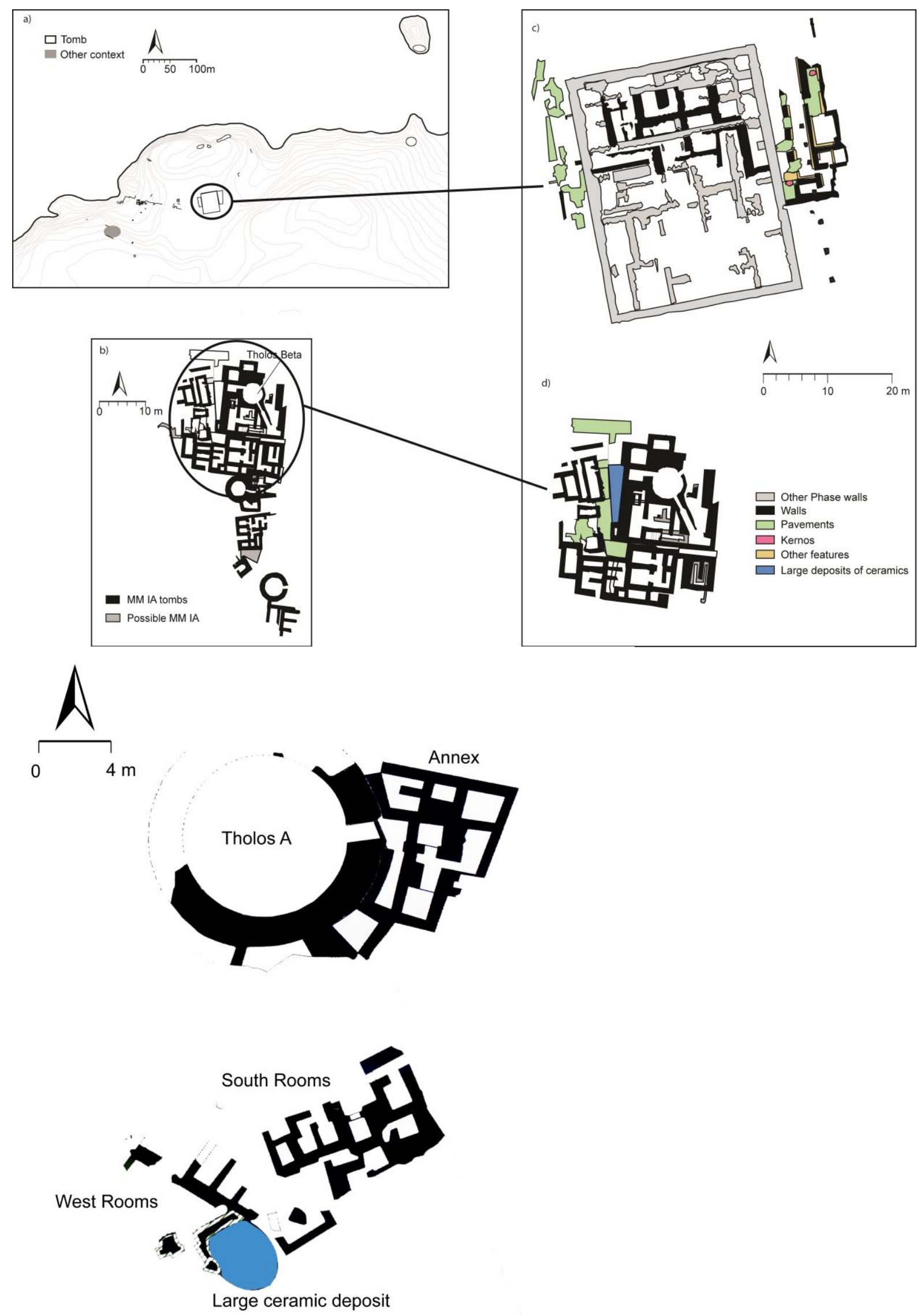
a)
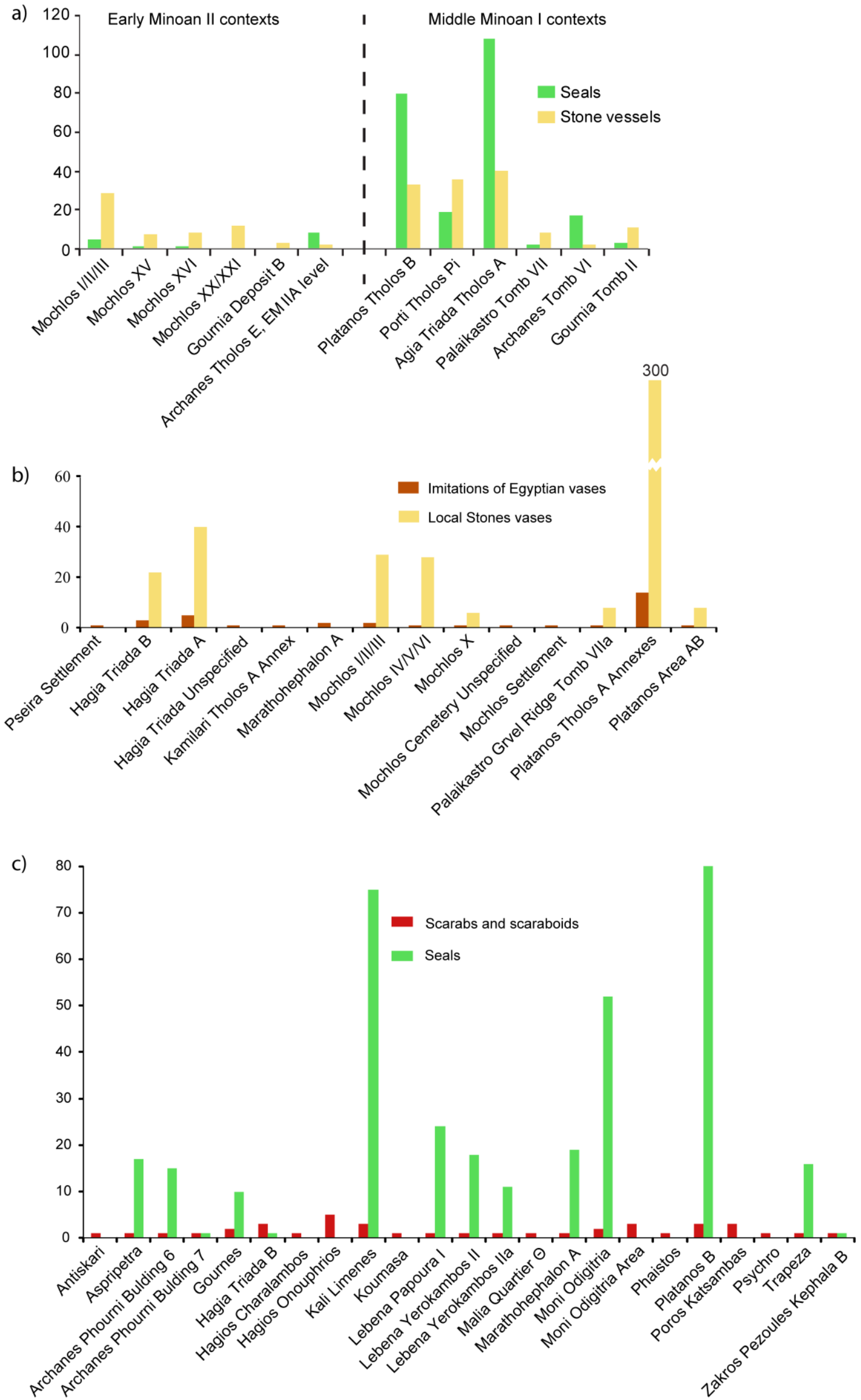


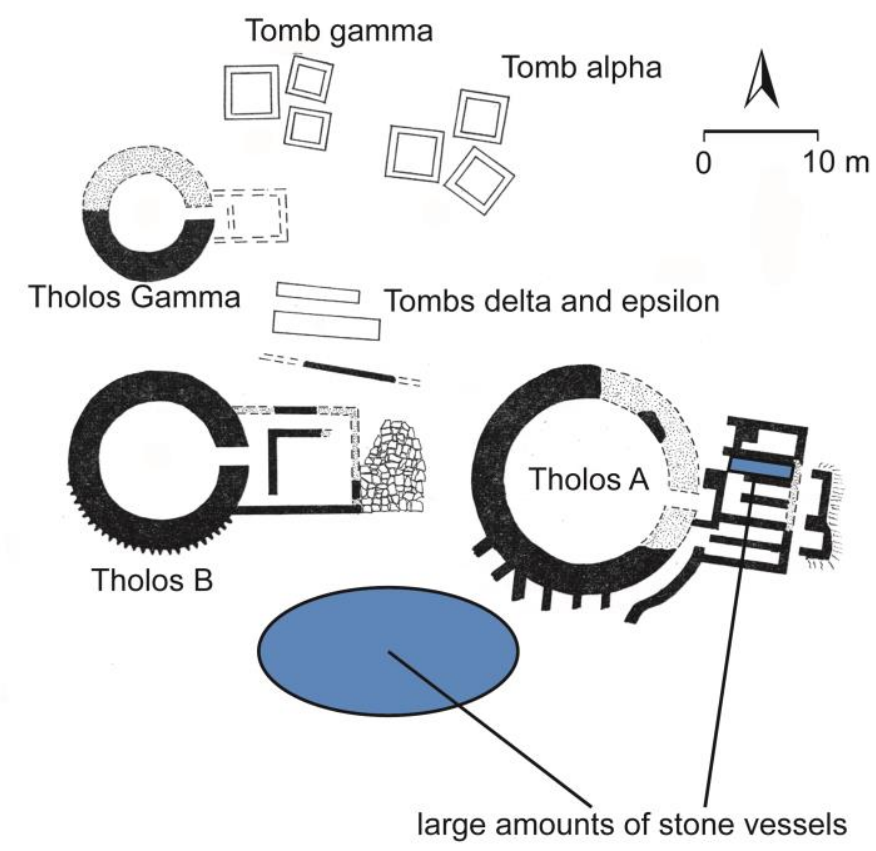

